\title{
Factory Workers in Tanzania: The Case of Chinese Enterprises at Mkuranga Industrial Park
}

\author{
Migeto Zakaria \\ PhD student: Minzu university of China
}

\begin{abstract}
FDI's plays are of great significance on economic development on both the host country and place of their origins. Tanzania's recent move of industrialization witnesses a handsome influx of Chinese foreign direct investments in special economic zone. With the increase of FDIs and industrial parks, cheap migrant labors are of great importance to the development of these factories in industrial zones. There has been speculation on mistreatments and misconduct of factory workers in Chinese enterprises. Western scholarship perceives Chinese presence in Africa as the predatory and Chinese workers are not only racist but belittle Tanzanians. On the other hand, Chinese scholarship sees Chinese investments in Africa as mutual beneficial between the two parties.Spending a year on different Chinese and one local owned company in Tanzania, this study employs a reflective model/grounded theory to study Chinese -Tanzanians work relation in industrial area at Mkuranga industrial park in Tanzania. This study discovered that, there is exploitation of unskilled labor through lower wages, unequal treatment of women in factories, skilled labor and those with basic Chinese language skills are treated differently. The study also discovered that, there is racialization of labor in factories. The kind of racialization exists in this factories is however different from that exists between Indians and Tanzanians. The difference is based on the extent of "oppressiveness" as Chinese seemed to be more considerate to workers than Indians.
\end{abstract}

Keywords: migrant, workers, factory, racialization, Tanzania.

DOI: $10.7176 / \mathrm{DCS} / 10-5-04$

Publication date:May $31^{\text {st }} 2020$

\section{Introduction}

Africa was hopeless, corrupts and not just not a place to do business. But suddenly everything changes. Suddenly, Africa I s the place to be and foreign investments is flooding in, and foreign powers are coming back, some with even upscale influence than ever. Listening to the west and the Chinese you would think that they are in Africa to help Africans to help themselves. France wants to help Africa build democratic institutions, the Americans wants to help Africa to build security structures and the Chinese wants to help Africa build economic infrastructure. The question is, is Africans benefiting from the competition or is being squeezed by this new scramble.

Unlike western powers, Chinese influence to Tanzania officially started soon after Tanganyika's independence. Tanganyika, the great bulk of today's Tanzania, established diplomatic relations with the People's Republic of China on December 9, 1961, the very same day that it gained independence. Former Chinese Premier Zhou En Lai visited Tanganyika in January 1964 to set diplomatic relations in motion. When Tanganyika faced a mutiny by its army in January that year, China acted promptly to provide military assistance. China's assistance was the first to be publicly accepted by the Tanganyika government, marking the beginning of Beijing's support of the Tanzania People's Defense Force (TPDF) to this day.

The rise of China is among the most discussed and watched topics in the fields of African Studies and International Relations It is in 2000s when china engagements with Africa gained momentum. The time was marked by a very important milestone, the initiation of FOCAC which implies that china would expand its influence in Tanzania through investments.

International scholars' scrutiny is on what and how China is doing in Africa? This thesis aims to contribute the mostly discussed topic of Chinese enterprises operations presence in Africa/ Tanzania and what extents are Chinese embedded with industrial parks societies.

Chinese racialization on blacks is far different from the west. While Chinese government regards Africans states as economic partners and the relation is a win-win, it is however absurd to deny Chinese racialization of Africans labor and racist behaviors towards black Africans.

The study is based on examining Chinese factory investment (Tang Co. pseudonym) in one of Tanzania newly established industrial park on the coast region of Pwani and SINOMA Tanzania group in three perspectives, 1) industrial parks factory workers; migrant peasant workers who move from unproductive peasant farming to newly industrial towns 2) Views and perspectives of Chinese/ Tanzanians workers in Tanzania; personality and 3) Chinese racialization of labor in the factories and industrial park..

Based on direct participation on the field work on one of factory in the industrial park, I argue that Chinese factories provides handsome employments opportunities to young migrant laborers, but the unskilled labors suffers from Chinese low salary, abuse and racialization in the factory. However having different cultural background misunderstandings are usually common during working time or even on social interactions. 


\section{Chinese Enterprises in Tanzania}

Three presidents have already passed since Tanzania's move from socialist self-reliance economic approaches and shifted focus towards integration of Tanzania into the world economy through trade and investment. In 2000s there were not only very few Chinese enterprises in Tanzania but also fewer articles on Chinese investment appearing in the news economy Fujita M (2017). Intensive investment commitment stared in 2000 at China - Africa Cooperation (FOCAC) in Beijing where China declared was to expand investments and tourism cooperation with Tanzania which will benefit the two countries. In 2000s China's co-operation with Tanzania in particular has largely focused on agriculture Fujita M (2017). The cooperation where based on agricultural machinery which aimed at modernizing agriculture in increase production staple foods like rice and maize for export. Fujita M (2017) cited Xinhua net that, In 2006 China and Tanzania made a US\$ 17.5 million agreement to finance investments in agriculture ${ }^{1}$.

The fifth president of Tanzania, president Magufuli aims at reaching the millennium goals of transforming Tanzania's economy to middle income economy by 2025 . He has developed another strategy that encourages economic growth through industrialization which is in some ways similar to Nyerere's vision. Foreign investments to Tanzania seems to align with president Magufuli industrialization move as Fujita M (2017) noted that the Chinese policies from 2015 to 2018 (2015 Magufuli came to power) also focus on industrialization and modernization of agriculture. According to Tanzania economic outlook report of 2016, Agriculture in Tanzania is an economic mainstay not only main contributor of GDP (In 2015 the agricultural sector contributed $29 \%$ of the GDP compared to $28.8 \%$ in 2014$)^{2}$, but also provide employment to most of common Tanzanians most of them are peasant farming. Discussed above, economic and environmental hardship peasants are facing in Tanzania to extent of choosing migration to towns as a livelihood strategy; migration to industrial Chinese investments enterprises is young peasant's livelihoods strategy. The main aim of president Magufuli is to diversify the peasant economy reliance to industrial hence the initiation of industrial parks in Tanzania. According to Burke and Corkin, more than 85 Chinese-funded enterprises are active in Tanzania, and the number of Chinese entrepreneurs active in services such as construction, health and restaurants are ever-growing Christopher and Corkin, Lucy (2006) worth of US\$2,142m of $\mathrm{FDI}^{3}$. However these investments of industrial parks are located in Dar es salaam (coast city), while agricultural and mining in other inland Tanzania's region including the Kilimo Kwanza (Agriculture First) initiative and the Southern Agricultural Growth Corridor of Tanzania (SAGCOT) partnership. To mention a few, there is there is an economic processing zone which is 12 kilometers from Dar es Salaam port and $14 \mathrm{~km}$ from Julius Nyerere International Airport, the 65-acre Benjamin Mkapa special economic zone, 300-acre Kamal Industrial Estate in Bagamoyo District and the newly developed Mkuranga Kisenvule industrial park ${ }^{4}$.

\section{Chinese Factory Enterprises in Mkuranga, Tanzania}

As discussed above, there is increasingly large quantity of Chinese investments in Tanzania, from construction, mining to factories. This article intends to study factory workers in Chinese enterprises and Chinese-local workers interaction in working and living place. However during analyzing, comparisons will be made with other noneChinese factories presence in Mkuranga industrial park. But first let's look on Chinese factories at Mkuranga industrial park.

Mkuranga industrial park is located at Mkuranga district, Pwani region few kilometers from business city of Dares salaam in Tanzania. At a time of my field work, there were eight factories available at Mkuranga, Kisenvule industrial area; five of them where Chinese owned factories, two India owned while one were locally owned but none operational. My field work was based at candy factory which is located at Kisenvule; however I had a chance to visit neighboring Chinese factories, one Indian owned cement factory. The other four Chinese factories; one manufactured plastic home utensils, the other assembled motorcycle, another one manufactured iron sheets and the last one manufactured tiles. Apart from the Indian cement factory all these Chinese factories were newly constructed and have been in operation not more than five years.

Tang Company is one of the factories located at Mkuranga industrial park at Kisenvule Township. This is candy factory was built in 2014; by 2015 it started its operation, due to unreliable market at the beginning, the factory started with very few factory workers.at the beginning there were 12 workers who ten of them were male workers; one local newly graduated engineer while other followed what he direct them to do. According to the company owner, administrative structure is two Chinese engineers at the bosses, and then followed by a Chinese translator (Chinese nationality) then the local newly graduated machines' operator, then at the bottom are the normal factory workers. By the end of 2016 the factory increases up to 25 permanent workers whom more than

\footnotetext{
${ }^{1}$ Xinhuanet, "China donates agricultural machinery to Tanzania, "Forum on China-Africa Cooperation, November 17, 2015, , accessed March 14, 2017, http://www.fmprc.gov.cn/zflt/eng/jmhz/t222842.htm.

${ }^{2}$ https://www2.deloitte.com/content/dam/Deloitte/tz/Documents/tax/Economic\%20Outlook\%202016\%20TZ.pdf. Accessed August $9^{\text {th }}$, 2019,

$3: 43 \mathrm{pm}$

${ }^{3} \mathrm{https}: / /$ nexia.com/insights/global-insight/investing-in-tanzania/. Accessed August 9, 2019

${ }^{4}$ https://www.trademarkea.com/news/tanzania-economic-zones-key-to-industrialisation-says-meru/. Accessed August 9, 2019
} 
$60 \%$ of them were female. However temporary factory workers varies from 20 to 30 workers, gain most of who are female workers due to "nature of work" in the factory which required sharp hands (according to owners request).

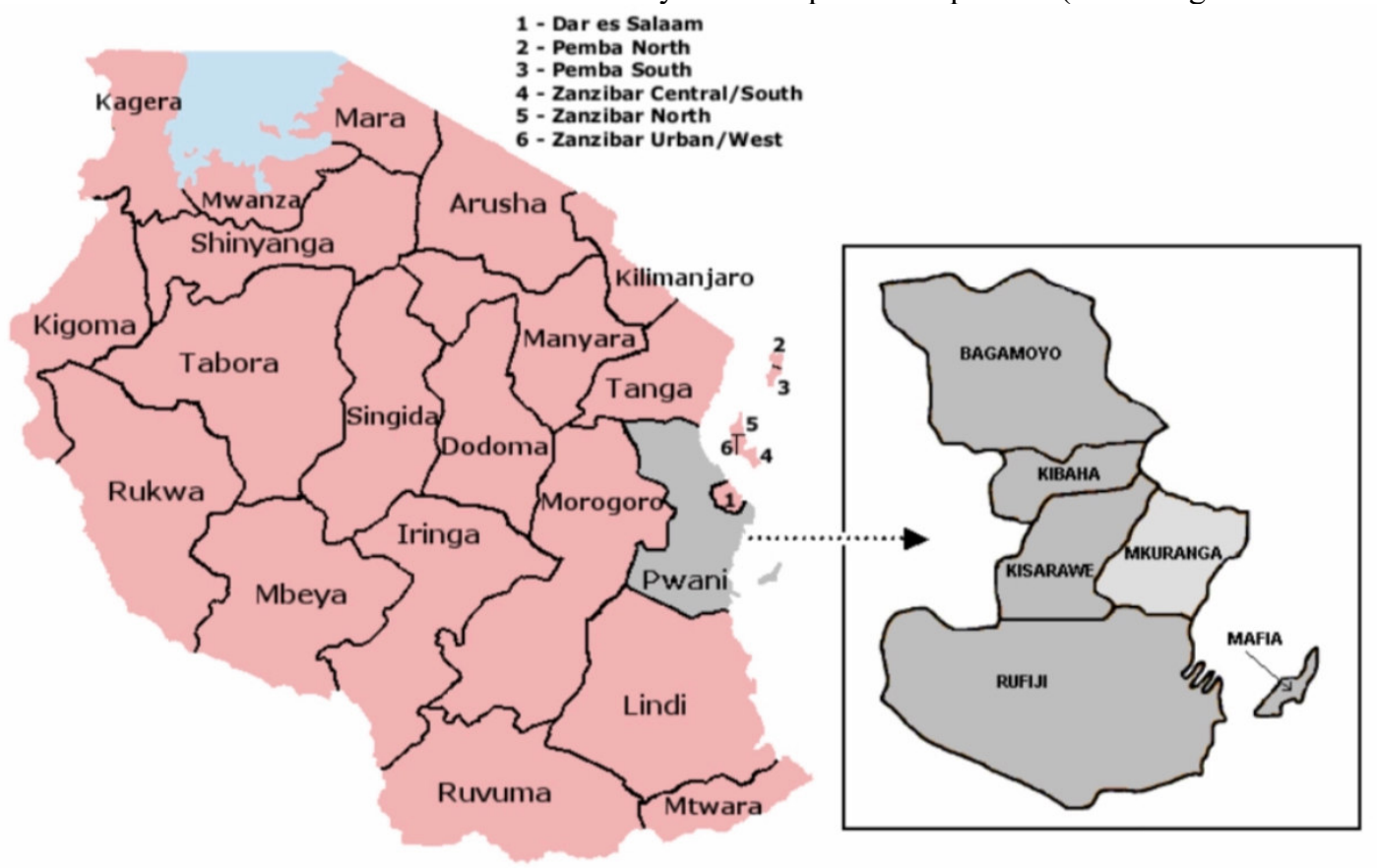

Figure 1: Map of Tanzania and the Mkuranga District

\section{Labor Appropriation Techniques in Factories}

Traditionally labor appropriation on economic development zones is unique in its use of temporary labor from rural areas. The mobilization of migrant labor or casual labor, which in china is termed as temporary labor, is one of distinctive elements of capitalism development in both developed countries in last century and in newly developing century (Burawoy 1976).

Tanzania's industrial zones like china's Shenzhen industrial zones at its early stage depends on mobilization of rural labor as the cheapest labor supply as part of the process of primitive accumulation in industrial/factory development. Different from china, Tanzania labor movement are not controlled (through hukou in china), different push and pill factors facilitate the movement of peasant migrant labor to industrial town. Industrial zones are new phenomenal in Tanzania and most studies bases on international migration little domestic migration, even those shows domestic migration are outdated and don't explain current Tanzania industrial economy and its source of cheap labor K. Beegle , (2011), Beegle et al, (2011). Therefore there are few currently studies showing migrant labor (migrant workers) in industrial areas rather labor migration in towns and big cities.

Labor appropriation in Tanzania's industrial zones is based on peasant young migrant farmers migrating to these Inderal towns as unskilled factory workers. Inlanders boys and girls choose migration as their livelihood strategy to go to different towns seek for work. The recently Tanzania's move of initiation of industrial towns to attract foreign and domestic investments witnesses massive migration of young people seeking for jobs in factories.

There are several determinant acts as pushing and pulling factors of peasant migrant workers to industrial town in Tanzania. First of all, Tanzania labor migration went as far back as during colonial administration where colonialists established large estates of tea and coffee in the southern highlands and northern highlands of Kilimanjaro and sisal at the coast regions including Morogoro, Tanga, and Pwani etc... W. Rodney argued, the politics of production (labor process and labor apparatus) based of establishment of different tax policies like hut tax and head tax so as to create a condition for islanders(Buha, Sukuma, Nyamwezi and Ha ethnic group) need to look for money for tax payments. On describing the Buha's role as labor reserve, he argued, the Ha were pushed into becoming migrant labor by colonial taxation and the monetization of social relations (especially bride wealthy), by administrative pressure and by absence of alternative ways of earning money, which was partly a result of the lack of official encouragement for cash crops W. Rodney, K. Tambila and L. Sago (1983)

After colonial era, newly independent Tanzania's migration in more that of running from unproductive peasant economy for better city or town job. Government agricultural policy was less friendly in favor of peasants to industrial developments. It can simply be understood that African countries agricultural policies is the culprit for the migration because of the condition it creates in rural areas and peasants. According to Robert Bates there are government interventions in three major markets. The first is market for agricultural goods which African government creates a single monopsony to buy peasants agricultural inputs in lower price. Second is market for 
inputs of farming which implies that governments provide little incents to peasants in Africa. The last is market for goods that farmers buy from urban-industrial sector in sense; these goods are of higher prices that peasants can't afford regarding that they income from agricultural goods reduced. Bates concluded that governments in Africa intend to transform their economies, they want to move resources from agriculture to industry and therefore they set agricultural goods prices in order to capture resources from agriculture Robert Bates (2014).

Many literatures however have linked migration to towns with climatic change that influence peasant farming in Africa/ Tanzania Clionadh Raleigh, Awil Mohamoud, Alpha Kaloga \& Sönke Kreft, (2014), Caroline Zickgraf, (2019). Study shows that Africa contributes to about 7 percent of global greenhouse gas emissions. Yet it remains highly vulnerable to the projected impact of climate change. According to World Bank Climate change is one of the biggest long-term challenges to global development. Africa is the hardest hit region in term of catastrophic natural disasters. The high vulnerability of the continent to the negative impact of climate change results from the fact that Africa as a whole has a high dependence on peasant farming, natural resources, poor infrastructure, pervasive poverty and weak institutional capacity to respond and mitigate environmental disasters effectively. In addition, the continent has a limited adaptive capacity, exacerbated by widespread poverty and the existing low levels of development Awil Mohamoud, Alpha Kaloga \& Sönke Kreft. (2014). The repercussions of climate change in Africa are, as observed so far, largely manifesting in changes in rainfall, accelerated deforestation and desertification World Bank (2013). Awil Mohamoud, Alpha Kaloga \& Sönke Kreft cited IPCC (2007) that by 2050, average temperatures in Africa are predicted to increase within a range of $1.5^{\circ} \mathrm{C}$ to $3^{\circ} \mathrm{C}$, while continuing to further increase beyond this time. Annual and seasonal warming throughout the African continent is very likely to be above the predicted global mean, with drier subtropical regions warming more than the moister tropics IPCC (2007). Therefore low rainfall leads to small yields hence famine therefore peasant farmers choose migration as their livelihood strategy.

\section{Factory Workers in Work Place}

According to traditional Marxism, development of capitalism owes much to the use and exploitation of labor. Labor is recruited through confiscated method known as the politics of production. Politics of production is where; labor process - the social relation in which men and women enter as they transform raw materials into useful products with instruments of production. It also includes political apparatus which reproduce those relations of the labor process through regulation of struggle Michael Burrawoy, (1985).

Industrial economy mostly relies on migrant short timed rural labor/ labor power from rural areas. How is that labor power, the capacity to work is translated into sufficient labor, application of effort, so as to provide both wages and profit? Marx answers, through coercion. In his analysis he argues, the coercion is done by factory regime through markets despotism. Here despotic regulation of the labor process is constituted by the economic whip of the market. Workers dependence on cash earnings is inscribed in their subordination on the factory Lycurgus.

In the current industrial capital world, huge number of labor is needed to work in factories in industrial parks. Taking example on China's industrial takeoff which depended solely of peasant migrant labor which proved to be cheap, easy to manage and submissive for factory work. At time of industrial take off, china have an organization which control labor movements (through hukou) (Shenzhen labor service company), and this Shenzhen labor organization has links with factories and works hand in hand with them regarding labor appropriation as was the official for labor supply under the control of Shenzhen labor bureau (Pun 2005) the purpose of the company is to regulate the transfer of labor from inland china to Shenzhen.

\section{Factory Division of Labor}

The gender division of labor refers to the allocation of different jobs or types of work to women and men W, Elizabeth (2007). Division of labor and use of machinery has been one of the effective methods to increase the output per worker T, Bruno (2013), E Durkheim (1984). In most of factories in this industrial area division of labor is however based on gender and education level. The study discovered that there is division of labor in this industrial area, male workers tends to do more of manual heavy lifting works and machine operations while female do light manual labor such as packing and packaging. On top of that female labors tend to be more of a part time compared to men. Winfred Osimbo Lichuma (2002) argued, gender inequalities are experienced in industrial labor in Kenya and women are mostly discriminated and marginalized. Most women interviewed were engaged as casual laborers. Women production in Kenya industrial labor was found to be very low as compared to men. However the research result found different results on amount of labor employed in industrial area in Tanzania. 60\% of workers working at least at this particular factory are female, who of course their labor is usually temporary and easy to get replaced. In all the factories I visited in this industrial town, male works at machinery spot and their payments in little higher than women. Example in a day, in Tang Co which in this industrial park its considered the well-paying factory, earned about 8000 Tsh while women earned 5000Tsh and top of that most of the time men usually goes home after they finish production while female continue packaging till all the products are packed. 
In neighboring factories however; like in Chinese marble floor factory men earn about 5000 to 6000 Tanzania shillings per day while women 3000 to 4000 Tanzania shillings per day. In an Indian factory company men earned 5000 Tsh while women earned 4000Tsh. It is because of this low salary in these neighboring factories lead to long queue of temporary workers in Tang Co. factory every morning. I asked the boss for the reason paying little high compared to neighboring factories; he said he tries combat petty theft in his factory.

\section{Racialization of Labor in Chinese Factory}

The main purpose of racialization of labor is exploitation so as to ensure maximum profit in a capitalist firm. Sautman \& Yan Hairong wrote, racialization of labor aims at exploiting workers at higher rates under worse conditions, usually for worse pay'. Most seafarers are 'men of color from the Global South who experience unfair treatment due to their race or nationality, including low wages, physical abuse, and a bar on contacting unions.

Racialization at Chinese firms in Africa is different from racialization of Africa from global north racialization of global south. Racialization at Chinese firms in Africa is co-constituted by Chinese employers and workers in Africa; Chinese in China; Africans at Chinese companies; African politicians, media, and intellectuals; and their Western counter parts. Theirperspectives actions form 'overlapping racialization [in which] there are multiple levels of complexity in interracial relations, which may involve both confrontation and collaboration Barry Sautman \& Yan Hairong (2016)

Barry Sautman \& Yan Hairong (2016) argues Chinese racialization at firms in Africa lacks most characteristics set out for North-South invested enterprises. Even the rhetoric differs. Unlike the Americans Bonacich discusses in relation to workers in China, Chinese in Africa do not conceive that Africans workers are grateful for low wages or steal their home country jobs, lower labor standards, or shun struggle. They view labor standards in some African states as higher than in China. However Barry Sautman \& Yan Hairong argument is not entirely true, in my time of working at a one Chinese factory, one Chinese office, and a wholesale Chinese enterprises in Kariakoo dares salaam Tanzania, I observed a maximum pay of 6000 to 8000 Tsh a day ( 1 dollar is equivalent to $2200 \mathrm{Tsh}$ ). At the time I was at Tang Co, the most paid African worker was an graduate degree engineer whom at the beginning was paid the same like unskilled migrant labor. Later due to his skillful expertise his salary increased up to $350,000 /=$ a month. Few months later, a Chinese worker from china joined the factory. He was a newly graduated with major in English language. Usually Chinese workers salaries are kept as secret to Africans workers. I managed to find out that he was paid $1624818.25 /=\mathrm{TSH}$.

Comparing Chinese to Indians racialization towards black people studies shows, Indians are the worst. A former bodyguard t Nelson Mandela Sam Prakash was quoted by the citizen saying Indians are the most racist in the world ${ }^{1}$. Although there is passive racism in china like being denied a job or lower salary due to being black in china or rudely photographed, but black people ${ }^{2}$; students in India are sometimes spat on, insulted and when renting apartments are being charge three times ${ }^{3}$.the study found that, Chinese employers provide higher salary than Indian investors. Monetarily, they (Chinese investors) argue that, Chinese employers pay more than other competitors Maho Fujita (2017). For example, Tang Co. pays 8000Tzs for a day, while another competitor, Simba cements co. (India cement company) pay 5000Tzs. They claim that Chinese give locals enough monetary incentive Maho Fujita (2017)

There currently are handsome amount of Indians who have been in Tanzania for decades. They do understand Tanzania culture and values and they live in the society together with Tanzanians. But they don't intermingle with black Tanzanians; the only mingling is during working hours. Majority of them lives in cities and towns and opens shops and factories. Workers employed in these shops and factories usually complain on Indians mistreatments towards black workers like pay cuts, salary delay etc.

At the time I was working at Tang Co, at the period of six months, four university graduate joined and left the company according to them due to unsatisfactory and mistreatments at the factory. One worked only for three month, some two while others didn't even last a month. They used these factories at this industrial park as their stepping stone to a better job. Two of them I know went to Tanzanian owned Coca-Cola Company.

On my field study experience, I moved from one company to another first of all due to low salary, and second I wanted to make a comparative study between different enterprises in Tanzania. My first Chinese company was Tang Co, due to being a fresh master's graduate with Chinese language skills, I was paid 800000TSH. I worked for five month, and then I went ahead and work at Kariakoo. Kariakoo is one of Tanzania's biggest market place with an increasing number of Chinese big and petty business men and women. At Kariakoo, this enterprise was owned by a Chinese business woman who imports mainly mosquito's nets, fancy curtains, among many. At this Chinese enterprise I was being paid much high than previous job, 15000000 TSH. My salary was much high than

\footnotetext{
${ }^{1}$ https://citizen.co.za/news/south-africa/2015127/watch-indians-are-the-most-racist-in-the-world-says-mandelas-former-bodyguard/ accessed August 22, 2019.

${ }^{2}$ https://medium.com/@jakepagano/african-students-encounter-institutional-racism-at-a-top-chinese-university-raising-urgent-cd8a6eeb1 fa4. accessed August 22, 2019.

${ }^{3}$ https://fotoroom.co/african-portraits-mahesh-shantaram/ August 22, 2019.
} 
the workers I found there not because I high higher education, but boss wanted only my Chinese language expertise and on her own words "I understand her and Chinese culture".

I worked there for three month before I joined a Tanzania-Kenyan's co-owned factory in Arusha. At this factory I was responsible in managing Chinese workers who were engineers at this factory. It is at this factory I saw the difference from Chinese enterprises. Salary became high, I was provided with a house and a transport. We worked six days a week and I stayed at that company for 2 month. May payments at this factory was 70 USD per day and was paid weekly.

My personal working story is similar to many graduate with the similar expertise like was, they only work in Chinese enterprises temporality unless high salaries are offered. Most of Tanzania workers I worked with during my field study time prefer to work at white owned companies or local owned companies which have local and foreign workers too. According to them, at these companies, their labors are not racialized and are being treated equally like other foreign expats. Local owned companies pay its workers according to workers capability and expertise one holds not due to skin color.

On my winter holiday when I was working with SINOMA east Africa, a human resources lady started discussing with me salaries cut issues. At SINOMA, a project manager was being paid 2400000TSH, almost similar to some Chinese workers. She asked me do I think is proper a Tanzania project manager to be paid that much, similar to Chinese manager? I was perplexed did not know what to answer her.

In terms of socialization with locals, Barry Sautman \& Yan Hairong argues, in all their interviews they found that, Chinese in Africa live eat and socialize with local people way more compared to white or other people of color. They wrote "Most Chinese have far less cultural overlap with Africans than do Western expats, yet do not generally display the aloofness that scholars of racialization of labor note at developed country enterprises in the Global South. In other study Hairong Yan, Sautman Barry and Yao Lu argued that, most Chinese in Africa are not self-isolated and not more isolated in Africa than are other Asian migrants and whites there Hairong Yan, Sautman Barry \& Yao Lu (2018).

There are contradicting perceptions against Barry and Yan discovery as it is believed to be one sided. Kenyan journalists reported that Chinese workers did not want to share a table at lunchtime with their African colleagues, and that insults and humiliations were the order of the day ${ }^{1}$. Last year a Chinese worker in Kenya were caught in camera insulting Kenyan and Kenyans president by calling there that they are dirty and are monkeys ${ }^{2}$. As it is not enough a Chinese restaurant while operating without proper license issued a "no blacks policy" to eat and sleep at that Chinese restaurant and hotel ${ }^{3}$.

However in my experience across Tanzania I noticed Chinese in Chinese enterprises don't mingle and live together with locals with the exception on those who builds infrastructures like railways and highway...even them they have separate compounds and cafeterias with local blacks. In Mkuranga industrial area local workers live separate mostly in rented ghetto while the Chinese workers and bosses has apartments. Local workers are usually have to walk two to five $\mathrm{km}$ to their residence sometimes at midnight with their day pay on them risking being robbed all the time. Maho fujita's study in Tanga's Chinese enterprises wrote in abroad Chinese workers isolate themselves from the local community and tend to live together as a big family. People in Sinoma live together five minutes away from the construction site in a building they built up. They own a bus, which they collectively use to commute to the construction site from the residential place. In the residential place area has residence building, dining place and entertainment place. There are local servants who take care of housekeeping and patrolling. They also brought Chinese chefs from China, so that they are able to have Chinese food with local groceries all the time. In the dining place they have a cafeteria style big space as well as Chinese style dining table. During relaxing time, they play pool and watch TV. Sometimes they go to the local bars and have drinks with local people. Maho added these Chinese workers', their interaction with local people is limited since only a manager owns a car and there is limited transportation means.

At SINOMA Dar es salaam, Tanzanians workers and Chinese workers shared same office but different cafeteria. Upon establishing this SINOMA Dar es salaam group there were temporary building where Chinese day workers used to stay in, now are used as Tanzania workers dining rooms and sleeping rooms for company's drivers. These former temporary Chinese rooms are made of galvanized sheets therefore tends to be terribly hot on day time and very cold a night and on Tanzania's dry season. Since most of Chinese workers likes to go downtown city in bars, casino and stay late, drives after driving them back has to stay at these bad conditioned rooms else they have to pay transport home on their own. I however managed to interview three drivers working at a company owned by Somali in collaboration with a British person, he said "when our bosses return from casino they gave us one car to go home with the condition of returning it next morning safely".

\footnotetext{
${ }^{1}$ https://www.dw.com/en/the-racist-face-of-the-chinese-presence-in-africa/a-46223068. Accessed August 18. 2019

${ }^{2}$ https://edition.cnn.com/2018/09/06/africa/kenya-deports-chinese-racist-remarks/index.html. Accessed August 18. 2019

${ }^{3}$ https://www.thejournal.ie/kenya-black-people-china-2011639-Mar2015/. Accessed August 18. 2019
} 


\section{Personality}

In this subsection, the study intends to look at personal and social views of Chinese workers to Tanzania workers and vice versa. The focus of the study in this section is glance on people to people views across the two group of different nationality. Some studies conducted about Africans, Tanzanians views in particular towards Chinese shows that there is stereotyping of Chinese by Tanzanians that Chinese investors and workers are rude and persistent, yet not many people could not give specific examples of their interaction that made them think of this personality threat Maho Fujita (2017). In Kenya, Chinese who were constructing Mombasa Kenya railways were views by locals as they don't take into account the cultural differences. They are our guests but orientate strongly towards their own ideology, igniting matters,"1 There are also Chinese personal views on African workers that are lazy and unskilled. Although studies shows that this is merely a stereotyping too as it shows that those Chinese who worked in Africa their stereotyped views were eroded after sometime M Petersen and S Ali. (2018).

Many individuals commented on the personality of Chinese people in Tanzania. More than 80 stereotyped Chinese workers as rude but few provided specifics. IDD a factory worker for example said his Chinese boss usual yells at them even if they are late for 2 minutes, and they don't listen to any excuses. He however mentioned some behavior of randomly spitting and smoking even in the presence of kids.

For Chinese workers who were presence in Tang Company seems to thing local workers as individuals who never lacks excuses and they never admit even if it is their fault and cant independently work unless close supervisions.

\section{Work Ethic and Culture}

Chinese and Tanzanians have different culture and work ethics, therefore conflict of misunderstanding is due to prevail. Many Chinese business owners have been describing Africans/blacks as lazy. Chinese employers may speak of African laziness, but define it in terms of comparative work intensity, apply it also to Europeans, other non-Africans, and Chinese of certain regions, and see it as mutable Sautman, Barry, and Hairong Yan. 2014. Maho fujita wrote "A project manager of Sinoma who is a friend of Samera has been working in Tanzania for more than two years. He also has several experiences in other countries in Africa and Middle East. He described Tanzanian workers as lazy and mentioned it is hard to find skilled labor in Tanzania." But in my observation in Tanzania I discovered that is not entirely true, although there some individual who are basically tends to argue for their basic rights then ended up branded as lazy.

Upon my time of working as an assistant manager in one of the factory in industrial park in Tanzania, on my first day of working, my boss who is the owner of the company asked me to hire workers who come from inner land region. He asked me not to hire locals who according to him he said are lazy. I asked him why he think local labors are lazy and laborers from inner land region are hardworking he said "local laborers tends to complain a lot about salary, working time and don't like working overtime at all". I discovered these local laborers are not the same as migrant laborers from inner land Tanzania. They have economic options therefore tends to ask for their rights as Tanzanians with different cultures. There is a described working hours according to Tanzania labor law; According to the law, your normal working hours per day are 8 hours and these should not be more than 48 hours per week. By including the lunch and prayer time in hours of work, working hours should not be greater than 9 hours a day. In this and neighboring factories, investors don't pay lunch time and workers are allowed to go and pray but their salaries always get deducted according to time used in praying. Most of coastal workers are of Muslim faith which requires them to play five time a day, and inner land workers most of them are of Christian faith, most of them only plays on Sundays which a work free day. My Chinese boss asked me why these locals would go to pray while they don't have money in their pockets. For him he thinks they are just lazy. My observation concurs with Mato Fujitos that, the challenge of work ethic comes from a cultural/value difference between China and Tanzania as well as their responsibility of work.

Most of Chinese believes Confucianism ethics that; According to the Confucians practice, "leadership emphasizes a holistic concern for the welfare of employees, a concern for harmony in groups, teamwork, and selfsacrifice. At the same time, Confucian leaders are frugal and demand loyalty and dedication to the organization. They expect employees to work tirelessly for the good of the group, the organization, and the nation. They tend to be autocratic and maintain tight control over the organization. China, more so than most countries clings to its past, and current managerial values, beliefs, and practices are strongly influenced by its Confucian tradition Rarick, Charles A. (2008). This practice is way opposite with that of Tanzania.

It is just a stereotype that Africans are lazy. Most of workers in in this industrial town are hardworking individuals who sometime get off work at $2 \mathrm{am}$ in the morning. Some Chinese bosses admitted African workers being hardworking and easy to manage. Chinese factory bosses in Ethiopia especially appreciate the 'hardworking and quick at learning' women workers Shen (2013).

In terms of personality, studies shows that most of Tanzanians thinks Chinese are rude and persistent Maho

\footnotetext{
${ }^{1}$ https://www.dw.com/en/the-racist-face-of-the-chinese-presence-in-africa/a-46223068. Accessed August 18. 2019
} 
Fujita (2017). My observation in four Chinese owned enterprises in Tanzania noticed that, there is misunderstanding on what is rude and persistence. Almost all workers told me Chinese usually yells at them and speaks with them at very high tones, they (local workers) sometimes think their Chinese bosses uses insults them in Chinese language. I working with Chinese more than a year in more than two companies however noticed that's not entirely true. There are sometimes yelling at work place but not only to local workers, even Chinese themselves to among each other. I talked with five Tanzanians (studies in china and speaks good mandarin) who happens to be worked and two of them still works in Chinese companies and they said that, most of we Tanzania when Chinese speaks with us we think they are being rude and yelling at us, but that's just Chinese way of speaking. Chinese workers in Tanzania usually most of them don't speak Swahili, and their English are terrible therefore they use Chinese to communicate with people who don't speak Chinese. Most Chinese in Tanzania don't really understand Tanzania's culture and ways of communication hence the confusion.

\section{Conclusion}

China's influence is day by day growing in Africa. Understanding Chinese enterprises in Africa is very vital for the case of avoiding past mistakes which were done by the west. Even though the China-Africa two parties are both developing entities unlike west, there is always different views and perception and even treatments to each other. The west sees Chinese treatments to Africans as exploitative and inhumane; the Chinese thinks their treatment to Africans/ black people is based on mutual respect and win-win relations.

Even though governments to government's relation are at least based on mutual economic and political relations, there is a lot to do with people to people relationship between the two parties. A Chinese government treats African governments with much respect and insists china needs Africa more than Africa needs china, African countries also treats china with respect as they need china now more than ever. But the cultural, economic and political difference is producing malpractices of Chinese practices to Africans. One cannot deny Chinese citizen covert racism in Africa and covert and overt racism in china towards black peoples.

There is a lot to do to avoid malpractices of Chinese workers towards African workers and African workers to Chinese workers as well. Labor laws and policy in Tanzania prohibit such malpractices but Tanzania being a developing country is unable to implement these policies. There are time to time mistreatments of Chinese workers in industrial zones but very few reactions have been taken to stop it. There are also a lot of mistreatments of African workers and few efforts have been taken against those who did it.

The study suggests the two governments (Chinese and Tanzania) to enhance close supervisions on its people but also educate and understanding each other traditions and cultures so as to avoid maltreatments of the two parties' workers. Policy and supervision centers should be established in industrial zones to avoid theft and crime so as to create conducive environments for investors and residents. However factory workers demands should be met in accordance with Tanzania labor law so that these industrial parks at least should be of benefits to local people not just GDP.

\section{References}

Awil Mohamoud, Alpha Kaloga \& Sönke Kreft, (2014). Climate change, development, and migration: an African Diaspora perspective. Germanwatch e.V. Bonn

Awil Mohamoud, Alpha Kaloga \& Sönke Kreft. Assessing the Impact of Climate Change on Migration and Conflict*

Beegle et al, (2011). "Migration and economic mobility in Tanzania : evidence from a tracking survey ...

Burke, Christopher and Corkin, Lucy (2006). "China's interest and activity in Africa's construction and infrastructure sectors". November: Centre for Chinese Studies. Page 53. Available on http://www.ccs.org.za/wpcontent/uploads/2009/04/dfid-3rd-edition.pdf

Caroline Zickgraf, (2019).Climate Change and Migration Crisis in Africa ${ }^{1}$ Clionadh Raleigh etl Assessing the Impact of Climate Change on Migration and Conflict*

Charles A. Rarick. (2008). Confucius on Management: Understanding Chinese Cultural Values and Managerial Practices. Journal of International Management Studies, Vol. 2, No. 2,

Durkheim, Emile (1984). The Division of Labour in Society. Trans. W. D. Halls, intro. Macmillan: Free Press, London. UK

E Durkheim. (1984). The Division of Labour in Society. Trans. W. D. Halls, intro. Lewis A. Coser. New York: Free Press , 1997

Hairong Yan, Sautman Barry \& Yao Lu. (2018). Chinese and 'self-segregation' in Africa.

https://citizen.co.za/news/south-africa/2015127/watch-indians-are-the-most-racist-in-the-world-says-mandelasformer-bodyguard/ accessed August 22, 2019.

https:/edition.cnn.com/2018/09/06/africa/kenya-deports-chinese-racist-remarks/index.html. Accessed August 18. 2019

https://fotoroom.co/african-portraits-mahesh-shantaram/. Accessed August 22, 2019. 
https://medium.com/@jakepagano/african-students-encounter-institutional-racism-at-a-top-chinese-universityraising-urgent-cd8a6eeb1 fa4. Accessed. August 22, 2019.

https://nexia.com/insights/global-insight/investing-in-tanzania/. Accessed August 9, 2019

https://www.dw.com/en/the-racist-face-of-the-chinese-presence-in-africa/a-46223068. Accessed August 18. 2019 https://www.thejournal.ie/kenya-black-people-china-2011639-Mar2015/. Accessed August 18. 2019

https://www.trademarkea.com/news/tanzania-economic-zones-key-to-industrialisation-says-meru/. August 9, 2019

https://www2.deloitte.com/content/dam/Deloitte/tz/Documents/tax/Economic\%20Outlook\%202016\%20TZ.pdf. Accessed August $9^{\text {th }}, 2019,3: 43 \mathrm{pm}$

K. Beegle. (2011). Patterns of Migration in Tanzania

M Petersen and S Ali. (2018) Chinese Migrant Perceptions of Africans: Understanding Confucian Reflexive Politics in Southern Africa

Michael Burawoy. (1985)The Politics of Production: Factory Regimes Under Capitalism and Socialism

Pun Ngai. (2015), Made in China: Women Factory Workers in a Global Workplace

Sautman, Barry, and Hairong Yan. 2014a. "Chinese, Africans and the Discourse of Laziness.” Paper, Chinese in Africa/Africans in China Research Network conference, Guangzhou, December 13.

Shen,Xiaofang.2013."PrivateChineseInvestmentinAfrica:MythsandRealities.”Policy Research Working Paper 6311, World Bank. http://documents.worldbank.org/ curated/en/2013/01/17159618/private-chineseinvestment-africa-myths-realities.

T, Bruno (2013). Why and how do capitalists divide labor? From Marglin and back again through Babbage and Marx. Review of Political Economy, Taylor Francis (Routledge), 2013, 25 (2), pp.254-272. ff10.1080/09538259.2013.775825ff. ffhal-00763837f

W, Elizabeth. (2007). Explaining the Gender Division of Labour: The Role of the Gender Wage Gap 1CMPO, The University of Bristol

W. Rodney, K. Tambila and L. Sago. (1983), Migrant Labor in Tanzania during the Colonial Period. Hamburg: Institut für Afrika-Kunde

World Bank. (2013), Turn Down the Heat: Climate Extremes, Regional Impacts, and the Case for Resilience

Xinhuanet, "China donates agricultural machinery to Tanzania, "Forum on China-Africa Cooperation, November 17, 2015, accessed March 14, 2017, http://www.fmprc.gov.cn/zflt/eng/jmhz/t222842.htm. 